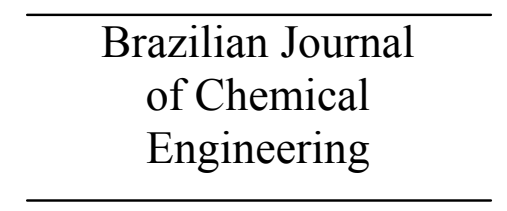

ISSN 0104-6632

Printed in Brazil

www.abeq.org.br/bjche

Vol. 29, No. 02, pp. 211 - 219, April - June, 2012

\title{
NITROGEN REMOVAL FROM LANDFILL LEACHATE VIA THE NITRITE ROUTE
}

\author{
D. Kulikowska* \\ Department of Environmental Biotechnology, University of Warmia and Mazury in Olsztyn, \\ Phone: + 480895234145, Fax: + 480895234131, Słoneczna St. 45 G, 10-709 Olsztyn, Poland. \\ E-mail: dorotak@uwm.edu.pl \\ (Submitted: May 18, 2011 ; Revised: September 20, 2011 ; Accepted: November 2, 2011)
}

\begin{abstract}
The feasibility of removing nitrogen from mature landfill leachate using the nitrite route was investigated in a two-stage SBR system $-\left(1^{\circ}\right.$ first stage, short-cut nitrification; second stage, denitrification via nitrite. With a volumetric exchange rate (n) of $0.3 \mathrm{~d}^{-1}$ and an oxygen concentration of between 1.2 and $1.3 \mathrm{mg} / \mathrm{L}$, the nitrite accumulation ratio $-\left(\mathrm{NO}_{2}-\mathrm{N}\right) \times 100 /\left(\mathrm{NO}_{\mathrm{x}}-\mathrm{N}\right) \%$ - was between $32 \%$ and $37 \%$. For the same hydraulic retention time, but lower oxygen concentration - between 0.8 and $0.9 \mathrm{mg} / \mathrm{L}$ - nitrite accumulation averaged $96 \%$, indicating that ammonia was removed completely via the nitrite pathway. In the second step, an external carbon source was added to promote denitrification. Complete removal of nitrite was obtained for a carbon dose of $2.4 \mathrm{mg} \mathrm{COD} / \mathrm{mg} \mathrm{NO}_{2}-\mathrm{N}$ using acetic acid and $3.8 \mathrm{mg} \mathrm{COD} / \mathrm{mg} \mathrm{NO}_{2}-\mathrm{N}$ for butyric acid. Also, a higher denitrification rate $-14.6 \mathrm{mg} \mathrm{NO}_{2}-\mathrm{N} / \mathrm{g}$ VSS $\cdot \mathrm{h}$ - was observed with butyric acid as compared with acetic acid $-9.12 \mathrm{mg} \mathrm{NO}_{2}-\mathrm{N} / \mathrm{g}$ VSS$\cdot h$.

Keywords: Landfill leachate; Short-cut nitrification; Denitrification via nitrite.
\end{abstract}

\section{INTRODUCTION}

The treatment of municipal landfill leachate has been considered to be very problematic because of its chemical composition. It is highly variable, heterogeneous, and depends on the type of waste deposited and the age of the landfill. Moreover, the leachate quality and quantity changes with time within the same landfill. According to the literature, apart from the organics and hazardous compounds, leachate contains a high concentration of ammonia nitrogen that could reach a few thousand milligrams per liter (Timur and Özturk, 1999; Kang et al., 2002; Kurniawan et al., 2006).

The operational costs of the biological nitrogen removal process mainly depend on the oxygen concentration and organic matter requirements for nitrification and denitrification, respectively. Therefore, some technological strategies have been developed during the last few years to reduce these costs. One of these is to short cut the biological nitrogen removal by partial nitrification-denitrification. In a conventional two-step nitrification, nitrite is produced as an intermediate from the oxidation of ammonia, which is then immediately oxidized to nitrate, resulting in a relatively low concentration of nitrite in the effluent. Partial nitrification and further denitrification via nitrite have attracted attention because they offer several advantages over conventional biological nitrogen removal via nitrate. In theory, these advantages include a $25 \%$ saving in oxygen consumption and a $40 \%$ saving in the carbon resource of the denitrification process. Therefore, these processes are economically favorable, especially in the case of wastewaters containing high concentrations of ammonia or characterized by a low carbon to nitrogen $(\mathrm{C} / \mathrm{N})$ ratio, e.g., landfill leachate.

Partial nitrification requires reducing the activity of the nitrite oxidizing bacteria (NOB), without affecting the ammonia oxidizing microorganisms (AOB). This can be achieved in several ways. The first is to use the difference in the activation energies

*To whom correspondence should be addressed 
between ammonia oxidation $(68 \mathrm{~kJ} / \mathrm{mol})$ and nitrite oxidation $(44 \mathrm{~kJ} / \mathrm{mol})$. The higher activation energy in the case of ammonia means that the process rate can be made temperature-dependent (Schmidt et al., 2002).

Other parameters conducive to short-cutting nitrification may be $\mathrm{pH}$ and dissolved oxygen (DO) regulation. However, in case of $\mathrm{pH}$, discrepancies are observed among the existing data (Villaverde et al., 1997; Ruiz et al., 2003; Wang et al., 2007). It is known that at low DO concentrations, ammonia oxidizing bacteria have a higher affinity for oxygen than nitrite oxidizing bacteria, so in activated sludge the first phase of nitrification dominates (Schmidt et al., 2003). Therefore, in this study, a low DO concentration was chosen as a technological parameter for investigating the possibility of nitrite accumulation.

The second step in nitrogen removal is denitrification. In leachate originating from mature landfill and characterized by a low chemical oxygen demand $(\mathrm{COD})$ to $\mathrm{N}$ ratio $(\mathrm{COD} / \mathrm{N})$, an external carbon source is needed to obtain high process efficiency. In the literature, there are some data concerning the doses of external organic carbon that are needed for nitrogen removal from leachate. However, most of these apply to nitrate reduction (Welander et al., 1998; Ilies and Mavinic, 2001a, 2001b; Klimiuk and Kulikowska, 2004; Kulikowska and Klimiuk, 2004).

Although the short-cut nitrification of wastewater with high ammonia concentration has been investigated in previous research, only a few studies on denitrification via nitrite have been done (Chung and Bae, 2002; Fux et al., 2006, Queiroz et al., 2011). Moreover, among these few, discrepancies in the data are observed. So, the $\mathrm{C} / \mathrm{N}$ ratio required for complete $\mathrm{N}-\mathrm{NO}_{2}$ reduction by denitrifying bacteria has not been confirmed and should be determined experimentally.

This study investigates the feasibility of short-cut nitrification with a low DO concentration as a parameter conducive to maximizing nitrite accumulation and denitrification. An external carbon source is introduced to enhance nitrogen removal via the nitrite route during the treatment of mature landfill leachate in a two-stage sequencing batch reactor (SBR) system. Additionally, a kinetic analysis was conducted. Acetic and butyric acids were chosen as external carbon sources because of the n-configuration of the volatile fatty acids (VFAs). Acids with two and four C-atoms - acetic and n-butyric acids - are stimulators of denitrification via nitrate (Eilersen et al., 1995). According to these authors, this might result from the ability of these acids to participate directly in the energy producing reactions in the bacterial cell. Moreover, Hallin and Pell (1998) pointed out that acetate and butyrate are easily converted by the bacterial cell to acetylo-CoA before entering the tricarboxylic acid cycle.

\section{MATERIALS AND METHODS}

\section{Leachate Feed}

The leachate used in this study was collected from a municipal landfill, which has been in operation since 1996, located at Wysieka (near Bartoszyce), Warmia and Mazury Province, Poland. In this landfill, only municipal waste (without fluid waste, fecal matter, hazardous substances, and radioactive and toxic waste) is deposited. The leachate composition during the period of the study is shown in Table 1.

Table 1: Composition of the raw landfill leachate

\begin{tabular}{|l|c|r|}
\hline Leachate constituent & Units & \multicolumn{1}{|c|}{ Value } \\
\hline $\mathrm{pH}^{*}$ & $\mathrm{mg} / \mathrm{L}$ & $8.1 \pm 0.14$ \\
COD* & $\mathrm{mg} / \mathrm{L}$ & $106 \pm 36.8$ \\
BOD5* & & 0.11 \\
BOD5/COD & $\mathrm{mg} / \mathrm{L}$ & $834 \pm 19.8$ \\
Total nitrogen* & $\mathrm{mg} / \mathrm{L}$ & $786 \pm 15.2$ \\
Ammonia nitrogen* & $\mathrm{mg} / \mathrm{L}$ & $48 \pm 6.2$ \\
Organic nitrogen* & $\mathrm{mg} / \mathrm{L}$ & $48.9 \pm 4.6$ \\
Total phosphorus* & $\mathrm{mg} / \mathrm{L}$ & $6730 \pm 625$ \\
Total dissolved solids* & $\mathrm{mg} / \mathrm{L}$ & $1280 \pm 110.5$ \\
Volatile dissolved solids* & $\mathrm{mg} / \mathrm{L}$ & $0.47 \pm 0.06$ \\
Zinc** & $\mathrm{mg} / \mathrm{L}$ & $0.081 \pm 0.025$ \\
Chromium** & $\mathrm{mg} / \mathrm{L}$ & $0.132 \pm 0.26$ \\
Cadmium** & $\mathrm{mg} / \mathrm{L}$ & $0.07 \pm 0.002$ \\
Cooper** & $\mathrm{mg} / \mathrm{L}$ & $0.03 \pm 0.0013$ \\
Nickel** & $\mathrm{mg} / \mathrm{L}$ & $\mathrm{bdl}$ \\
Lead** & $\mathrm{mg} / \mathrm{L}$ & $\mathrm{bdl}$ \\
Mercury** & \multicolumn{2}{|c|}{} \\
bdl - below detection limit & * measurement repeated five times \\
** measurement repeated three times &
\end{tabular}

\section{Process Configuration and System Design}

The landfill leachate treatment was carried out in the laboratory using a two-stage system consisting of aerobic SBR-N (nitrification) and anoxic SBR-D (denitrification) units (Figure 1). The system was operated at room temperature $\left(20 \pm 2^{\circ} \mathrm{C}\right)$. 


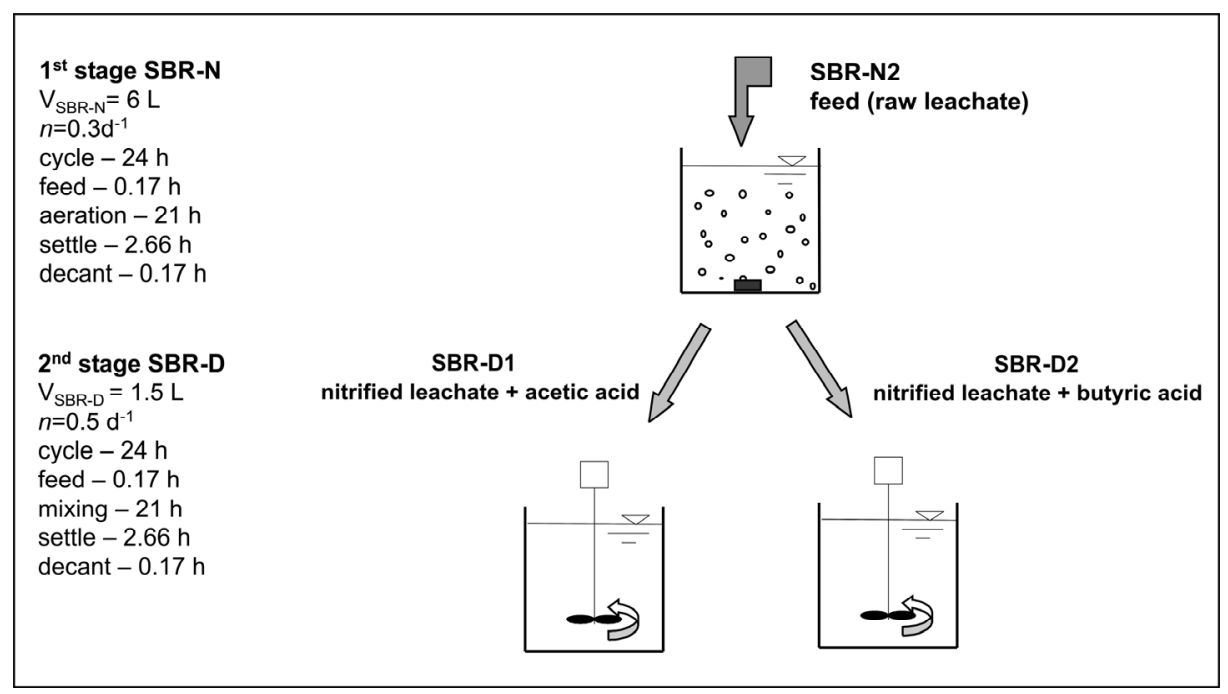

Figure 1: Schematic of the two-stage SBR system

\section{Nitrification}

Nitrification was investigated in two aerated SBRs operated in parallel. The SBRs, each with a working volume of $6 \mathrm{~L}$, were made of Plexiglass and were equipped with a stirrer (operated at a regulated rotation speed of $36 \mathrm{rpm}$ ) and a controlled air supply system. Air was supplied by porous diffusers placed at the bottom of the tank. The SBRs worked at a volumetric exchange rate (n) of $0.3 \mathrm{~d}^{-1}$. In both SBRs the filling period was short as a result of portion dumping of the leachate $(1.8 \mathrm{~L} /$ cycle $)$.

The SBRs differed in their DO concentrations. The amount of air entering the SBRs was automatically adjusted to a stable set-point of between 0.8 and $0.9 \mathrm{mg} \mathrm{O}_{2} / \mathrm{L}$ (SBR-N1) and between 1.2 and $1.3 \mathrm{mg} \mathrm{O}_{2} / \mathrm{L}$ (SBR-N2). Both reactors were operated in a 24-hour cycle mode with 0.17 hours for the feed stage, 21 hours for the aeration stage, and 2.83 hours for the settle and decant stage.

\section{Denitrification}

Leachate from SBR-N2 was subsequently fed into two SBRs (SBR-D1, SBR-D2) made of Plexiglass, with a working volume of $1.5 \mathrm{~L}$ each. The SBRs differed in their carbon sources (Table 2). In both reactors, the volumetric exchange rate, n, was $0.5 \mathrm{~d}^{-1}$. In the second system, the aeration phase was eliminated. The cycle time for SBR-D was 24 hours and the times for the various phases were: feed 0.17 hours, mixing 21 hours, and settle and decant 2.83 hours. The operating conditions in the denitrified reactors are listed in Table 2.
Table 2: Technological parameters in the second stage (denitrification via nitrite)

\begin{tabular}{|l|c|c|}
\hline Technological parameters & SBR-D1 & SBR-D2 \\
\hline Volumetric exchange rate $\left(\mathbf{d}^{-1}\right)$ & \multicolumn{2}{|c|}{$\mathbf{0 . 5}$} \\
\hline Type of external carbon source & acetic acid & butyric acid \\
External carbon source dosage & $2-3$ & $3-4$ \\
COD $/ \mathrm{N}_{\mathrm{NO} 2} *(\mathrm{mg} / \mathrm{mg})$ & & \\
\hline
\end{tabular}

*It was assumed that the leachate after the first stage (nitrification) contains only non-biodegradable organics $\left(\mathrm{BOD}_{5}\right.$ in the effluent $<6 \mathrm{mg} / \mathrm{L}$ ) and these were not considered when determining the dose of external carbon

In both processes (nitrification and denitrification), the adaptation period lasted between 30 and 40 days. After the biomass adapted to the experimental conditions and steady-state conditions were obtained, cultivation of the activated sludge was continued for 3 months.

\section{Analytical Methods}

The raw leachate was analyzed for:

- $\mathrm{pH}$ (pH-meter HI 8818);

- COD (according to Standard Methods, 1997);

- $\mathrm{BOD}_{5}$ (according to DIN EN 1899-1/EN 1899-2 official EPA method using OxiTop WTW Wissenschaftlich-Technische Werksträtten $\mathrm{GmbH}$, D-82326 Weilheim, Germany);

- Kjeldahl nitrogen, ammonia-N, nitrite-N and nitrate-N (according to the Standard Methods, 1997);

- total phosphorus (according to the Standard Methods, 1997);

- total dissolved solids and volatile dissolved solids (according to Hermanowicz et al., 1999);

- metals ( $\mathrm{Zn}, \mathrm{Cr}, \mathrm{Cd}, \mathrm{Cu}, \mathrm{Ni}, \mathrm{Pb}$, and $\mathrm{Hg}$ ) (according to $\mathrm{PN}-92 / \mathrm{C}-04570 / 02)$. 
Daily measurements of effluent from the SBR included $\mathrm{COD}, \mathrm{BOD}_{5}$, Kjeldahl nitrogen, ammonia-N, nitrate-N, and nitrite- $\mathrm{N}$, according to the methods given above.

In SBRs were analyzed:

- mixed liquor volatile suspended solids (MLVSS) and total suspended solids (MLSS) (according to Hermanowicz et al., 1999);

- oxygen concentration (using an oxygen controller).

\section{RESULTS AND DISCUSSION}

\section{Landfill Leachate Characterization}

For the leachate studied, the concentration of organic compounds, expressed as COD, was $896 \mathrm{mg} / \mathrm{L}$, but the proportion of easily biodegradable organics $\left(\mathrm{BOD}_{5}\right)$ was only $12 \%$. The total nitrogen concentration was $834 \mathrm{mg} \mathrm{N} / \mathrm{L}$ and the ammonium concentration was $786 \mathrm{NH}_{4}-\mathrm{N} \mathrm{mg} / \mathrm{L}$ (Table 1).

The leachate originated from a landfill that has been in use for over 10 years and, therefore, showed a good correlation with the low organic compounds content. A literature review revealed that leachate from stabilized landfills contains low concentrations of organic compounds, often below $1500 \mathrm{mg} / \mathrm{L}$ (Kang et al., 2002; Trebouet et al., 2001). Furthermore, recent investigations have revealed that even the leachate from young landfills contains low concentrations of organic compounds (Aziz et al., 2007). Some authors suppose that it is caused by leachate recirculation, which reduces the waste stabilization time, enhances gas production, and, consequently, lowers the leachate concentration, especially in terms of COD (Reinhart et al., 1996; Chugh et al., 1998; Chan et al. 2002).

The ammonium concentration in the leachate studied was about $800 \mathrm{mg} \mathrm{NH}_{4}-\mathrm{N} / \mathrm{L}$. Similar ammonia amounts have been reported previously (Kang et al., 2002; Trebouet et al., 2001; Avezzu et al., 1992). Leachate is rich in ammonia nitrogen as a result of the hydrolysis and fermentation of the nitrogenous fractions of the biodegradable substrates (Carley and Mavinic, 1991) and the release of soluble nitrogen from municipal solid waste into the leachate is slow and may continue over a long period.

\section{Organics Removal and Nitrification}

The removal and nitrification of the organic compounds were tested at oxygen concentrations of between 1.2 and $1.3 \mathrm{mg} / \mathrm{L}$ (SBR-N1) and between 0.8 and $0.9 \mathrm{mg} / \mathrm{L}$ (SBR-N2). In both reactors, the efficiency of organic compound removal as $\mathrm{BOD}_{5}$ was over $94 \%$ and the concentration of organics in the effluent was below $8 \mathrm{mg} / \mathrm{L}$. The efficiency of removal of the organics, expressed as COD, did not exceed $15 \%$. A similar result - an efficiency of removal of organics from municipal landfill leachate in Sweden of about 20\% - was obtained by Welander et al. (1998).

The efficiency of organic nitrogen removal was not high (about 10\%), which was probably the result of the low biodegradability of the N-containing substances in the raw leachate. It was shown that in SBR-N1 at $\mathrm{n}=0.3 \mathrm{~d}^{-1}$ and a higher oxygen concentration, the nitrite accumulation ratio, calculated as $\left(\mathrm{N}-\mathrm{NO}_{2}\right) \times 100 /\left(\mathrm{N}-\mathrm{NO}_{\mathrm{x}}\right) \%$ was between 32 and $37 \%$. In the effluent, apart from nitrites, the nitrate concentration was observed to be $167.2 \mathrm{mg}$ $\mathrm{N}-\mathrm{NO}_{3} / \mathrm{L}$, on average (Figure 2 and Table 3 ).

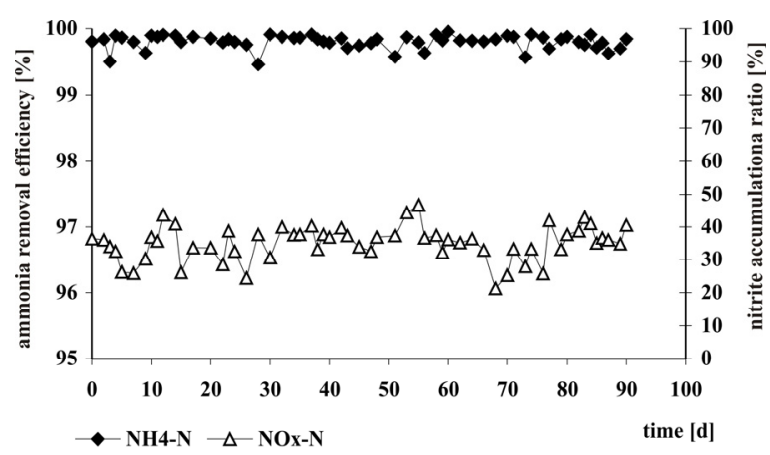

(a)

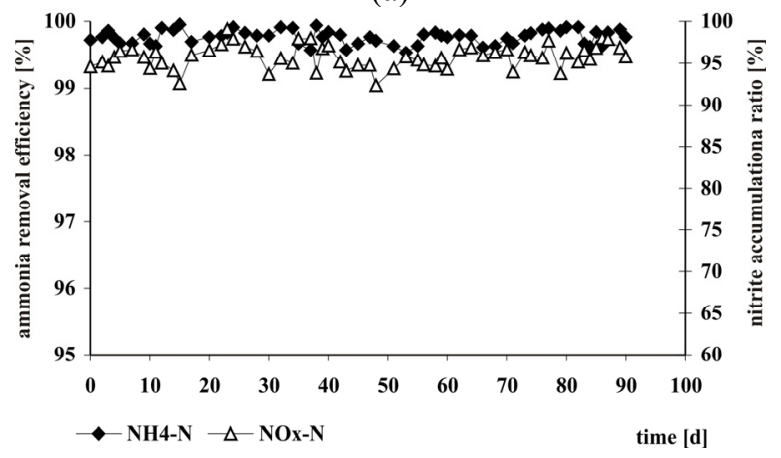

(b)

Figure 2: Efficiency of ammonia removal and nitrite accumulation ratio in SBR-N (a) SBR-N1; (b) SBR-N2

Table 3: Mean amounts" of the different nitrogen forms in the effluent from the first stage (shortcut nitrification)

\begin{tabular}{|c|c|c|c|}
\hline Dissolved oxygen & \multicolumn{3}{|c|}{ Nitrogen form in the effluent } \\
\cline { 2 - 4 } $\begin{array}{l}\text { concentration in } \\
\text { the SBR-N (mg/L) }\end{array}$ & $\begin{array}{c}\mathbf{N H}_{4}-\mathbf{N} \\
(\mathbf{m g} / \mathbf{L})\end{array}$ & $\begin{array}{c}\mathbf{N O}_{\mathbf{2}}-\mathbf{N} \\
(\mathbf{m g} / \mathbf{L})\end{array}$ & \multicolumn{1}{c|}{$\begin{array}{c}\mathbf{N O}_{\mathbf{3}}-\mathbf{N} \\
(\mathbf{m g} / \mathbf{L})\end{array}$} \\
\hline $1.2-1.3(\mathrm{SBR}-\mathrm{N} 1)$ & $0.49 \pm 0.36$ & $89.3 \pm 19.4$ & $167.2 \pm 34.5$ \\
$0.8-0.9$ (SBR-N2) & $0.62 \pm 0.29$ & $251 \pm 19.6$ & $11.4 \pm 5.2$ \\
\hline
\end{tabular}

*Mean values were determined from 58 measurements of each nitrogen form 
At the same $n$, but at a lower oxygen concentration, nitrite accumulation was at a level higher than $95 \%$, which indicates that nearly all the nitrogen was completely removed via the nitrite pathway. Since in both cases the sludge age was similar (26 days) and the process was conducted at a temperature of $20 \pm 2^{\circ} \mathrm{C}$, it may be supposed that the parameter crucial for obtaining short-cut nitrification was a DO concentration below $1 \mathrm{mg} / \mathrm{L}$. Similarly, Ruiz et al. (2003) showed that oxygen concentration is a crucial parameter for obtaining partial nitrification. These authors found that with a reactor DO concentration of $0.7 \mathrm{mg} / \mathrm{L}$, it was possible to accumulate more than $65 \%$ of the loaded ammonia nitrogen as nitrite with a $98 \%$ ammonia conversion. At DO concentrations below $0.5 \mathrm{mg} \mathrm{O}_{2} / \mathrm{L}$, the accumulation of ammonia nitrogen occurred, while at DO values greater than $1.7 \mathrm{mg} \mathrm{O}_{2} / \mathrm{L}$, full nitrification was obtained. However, Jianlong and Jing (2005) showed that in order to obtain a stable short-cut nitrification, apart from a low oxygen concentration $\left(1.5 \mathrm{mg} \mathrm{O} \mathrm{O}_{2} / \mathrm{L}\right)$, a high temperature $\left(30^{\circ} \mathrm{C}\right)$ was needed. At a temperature over $30^{\circ} \mathrm{C}$, the specific rate of growth of ammonia oxidizing bacteria is twice as high as the rate of growth of the bacteria oxidizing nitrite $\left(1 \mathrm{~d}^{-1}\right.$ and $\left.0.5 \mathrm{~d}^{-1}\right)$ (Mulder and van Kempen, 1997), which means that the high temperature is conducive to the rapid multiplication of the bacteria oxidizing the ammonia nitrogen (Hellinga et al., 1998; Mulder et al., 2001).

Based on the ammonium concentration profiles during the aeration phase of the SBR cycle, once steady-state conditions were obtained in both reactors, a kinetic analysis was performed (Figure 3 ).

An analysis of the experimental results showed that the ammonium removal rate was a zero-order kinetic process defined by the following differential equation:

$r_{\mathrm{NH}_{4}-\mathrm{N}}=-\frac{\mathrm{dC}_{\mathrm{NH}_{4}-\mathrm{N}}}{\mathrm{dt}}=-\mathrm{k}_{\mathrm{NH}_{4}-\mathrm{N}}$

The solution for this equation could be fitted to the experimental data according to:

$\mathrm{C}_{\mathrm{NH}_{4}-\mathrm{N}}=\mathrm{C}_{\left(\mathrm{NH}_{4}-\mathrm{N}\right)_{0}}-\mathrm{k}_{\mathrm{NH}_{4}-\mathrm{N}} \cdot \mathrm{t}$

where:

$\mathrm{C}_{\mathrm{NH} 4-\mathrm{N}}$ ammonium nitrogen concentration after time $\mathrm{t}\left(\mathrm{mg} \mathrm{NH} \mathrm{NH}_{4} \mathrm{~N} / \mathrm{L}\right)$

$\mathrm{C}_{(\mathrm{NH} 4-\mathrm{N}) 0}$ ammonium nitrogen concentration at the beginning of the SBR operating cycle (mg $\mathrm{NH}_{4}-\mathrm{N} / \mathrm{L}$ )
$\mathrm{k}_{\mathrm{NH} 4-\mathrm{N}}$ constant of the ammonium nitrogen removal rate $\left(\mathrm{mg} \mathrm{NH}_{4}-\mathrm{N} / \mathrm{L} \cdot \mathrm{h}, \mathrm{mg} \mathrm{NH}_{4}-\mathrm{N} / \mathrm{g}\right.$ $\mathrm{VSS} \cdot \mathrm{h})$

$\mathrm{r}_{\mathrm{NH} 4-\mathrm{N}}$ ammonium nitrogen removal rate $\left(\mathrm{mg} \mathrm{NH}_{4}-\right.$ $\left.\mathrm{N} / \mathrm{L} \cdot \mathrm{h}, \mathrm{mg} \mathrm{NH} \mathrm{NH}_{4} \mathrm{~N} / \mathrm{g} \mathrm{VSS} \cdot \mathrm{h}\right)$

$\mathrm{t}$ time (hours)

The rate of ammonium oxidation in both reactors is shown in Figure 3.

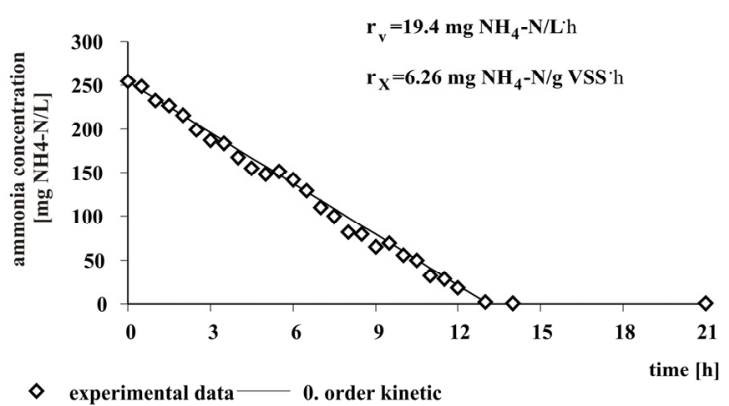

(a)

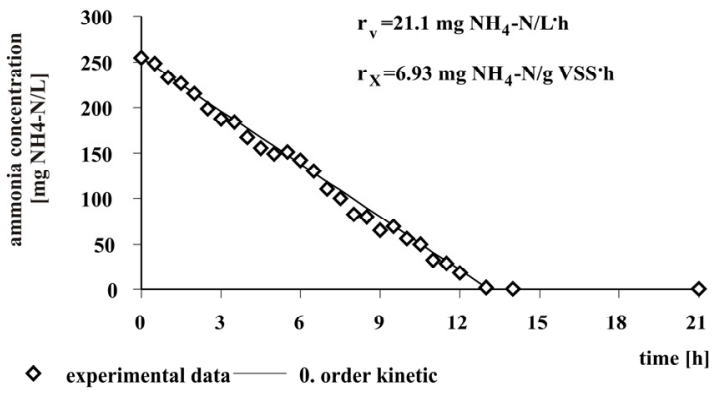

(b)

Figure 3: Concentration profiles of ammonia during aerobic conditions and short-cut nitrification rates described by zero-order kinetics: (a) SBR-N1; (b) SBR-N2

In SBR-N1, the nitrification rate was $6.26 \mathrm{mg}$ $\mathrm{NH}_{4}-\mathrm{N} / \mathrm{g}$ VSS·h and the time needed for the ammonium oxidation to nitrite was about 14 hours about $70 \%$ of the aeration phase. At a higher DO level, the ammonium removal rate was only slightly higher - $6.93 \mathrm{mg} \mathrm{NH}_{4}-\mathrm{N} / \mathrm{g} \mathrm{VSS} \cdot \mathrm{h}$.

\section{Denitrification}

In order to verify the efficiency of denitrification, the effluent from SBR N-2 (which contained only nitrite) was fed to two denitrification reactors (SBR-D1 and SBR-D2). These two reactors varied in their organic carbon sources (Table 2). The selection of the effluents with nitrite was dictated by two factors. The first was that the reduction of nitrite needs less carbon than the reduction of nitrates. In theory, the 
savings in carbon dosage should be $40 \%$, because nitrite is reduced by three electron equivalents per mol $\mathrm{N}$ and nitrate by five electron equivalents per mole $\mathrm{N}$. The second is that when nitrite and nitrate are present in the reactor, nitrite reduction is inhibited when the initial nitrate concentration is greater than $25 \mathrm{mg} \mathrm{NO}_{3}-\mathrm{N} / \mathrm{L}$ (Chung and Bae, 2002).

In both the SBR-D reactors, the denitrification process was investigated at COD to $\mathrm{N}-\mathrm{NO}_{2}$ ratios of 2, 3, 4, and 5. During the research for all tested organic carbon sources, the optimal organic $\mathrm{C} / \mathrm{N}$ ratio that resulted in the highest denitrification efficiency was determined.

In view of the mass of these results, in this study the denitrification efficiencies for the selected $\mathrm{C} / \mathrm{N}$ ratio - between 2 and $3 \mathrm{mg} \mathrm{COD} / \mathrm{mg} \mathrm{N}-\mathrm{NO}_{2}$ for acetic acid and between 3 and $4 \mathrm{mg} \mathrm{COD} / \mathrm{mg} \mathrm{N}-\mathrm{NO}_{2}$ for butyric acid - were studied and discussed.

Furthermore, the organic carbon doses for the complete denitrification of both the external organic compounds used were optimized. The optimization was obtained by increasing or decreasing the amount of the organic. The research results showed that the optimal organic to nitrate nitrogen ratio was $2.4 \mathrm{mg}$ $\mathrm{COD} / \mathrm{mg} \mathrm{N}-\mathrm{NO}_{2}$ for acetic acid and $3.8 \mathrm{mg} \mathrm{COD} / \mathrm{mg}$ $\mathrm{N}-\mathrm{NO}_{2}$ for butyric acid. In both cases, the $\mathrm{N}-\mathrm{NO}_{2}$ removal efficiency was over $99 \%$.

The $\mathrm{C} / \mathrm{N}$ ratio required for complete $\mathrm{N}-\mathrm{NO}_{2}$ reduction by the denitrifying bacteria depended on the nature of the carbon source and should be determined experimentally. However, most works have only taken into consideration the demand for carbon during conventional denitrification (nitrate pathway). Kaczorek and Ledakowicz (2006) showed that in the two-stage sludge system with secondary denitrification and sodium acetate as a carbon source (with a COD to $\mathrm{N}$ ratio above 4), the removal of inorganic nitrogen compounds from landfill leachate was $99 \%$. Carrera et al. (2003) showed complete denitrification using two different industrial carbon sources, one containing mainly ethanol and the other methanol (2003). According to their research, the $\mathrm{COD}$ to $\mathrm{N}$ ratio needed for denitrification using ethanol was $4.3 \pm 0.4 \mathrm{~g}$ $\mathrm{COD} / \mathrm{g} \mathrm{N}$ and for methanol was $3.9 \pm 0.5 \mathrm{~g} \mathrm{COD} / \mathrm{g} \mathrm{N}$. The results from the investigations of Christensson et al. (1994) show that the amount of COD required for nitrate removal was lower for ethanol $(3.85 \mathrm{~g} / \mathrm{g} \mathrm{N})$ than for methanol $(4.45 \mathrm{~g} / \mathrm{g} \mathrm{N})$ in the continuous experiments, while it was higher for ethanol $(6.1 \mathrm{~g} / \mathrm{g} \mathrm{N})$ than for methanol $(4.1 \mathrm{~g} / \mathrm{g} \mathrm{N})$ in pure culture batch cultivations. So far, only a few studies on denitrification via nitrite have been done. Moreover, among these few, data-discrepancies are observed. For example Akunna et al. (1993) showed that in the presence of glucose as a carbon source, ammonium accumulation was found and dissimilatory reduction to ammonium accounted for up to $50 \%$ of the reductions in nitrate and nitrite. In contrast, the research of Chung and Bae (2002) proved that glucose gave the fastest nitrite reduction rate.

On the basis of the nitrite nitrogen changes in the cycle of SBR-D, after the process had reached steady-state conditions, a denitrification kinetic analysis was done. The analyses showed that nitrogen reduction, regardless of the organic carbon source, was a zero-order kinetic process:

$\mathrm{r}_{\mathrm{NO}_{2}-\mathrm{N}}=-\frac{\mathrm{dC}_{\mathrm{NO}_{2}-\mathrm{N}}}{\mathrm{dt}}=-\mathrm{k}_{\mathrm{NO}_{2}-\mathrm{N}}$

The solution for this equation could be fitted to the experimental data according to:

$\mathrm{C}_{\mathrm{NO}_{2}-\mathrm{N}}=\mathrm{C}_{\left(\mathrm{NO}_{2}-\mathrm{N}\right)_{0}}-\mathrm{k}_{\mathrm{NO}_{2}-\mathrm{N}} \cdot \mathrm{t}$

where:

$\mathrm{C}_{\mathrm{NO} 2-\mathrm{N}}$ nitrite concentration after time $\mathrm{t}\left(\mathrm{mg} \mathrm{NO}_{2}-\mathrm{N} / \mathrm{L}\right)$

$\mathrm{C}_{(\mathrm{NO2}-\mathrm{N}) 0}$ nitrite concentration at the beginning of the SBR operating cycle $\left(\mathrm{mg} \mathrm{NO}_{2}-\mathrm{N} / \mathrm{L}\right)$

$\mathrm{k}_{\mathrm{NO2}-\mathrm{N}} \quad$ constant of the denitrification rate $\left(\mathrm{mg} \mathrm{NO}_{2}-\right.$ $\left.\mathrm{N} / \mathrm{L} \cdot \mathrm{h}, \mathrm{mg} \mathrm{NO} \mathrm{N}_{2} \mathrm{-N} / \mathrm{g} \mathrm{VSS} \cdot \mathrm{h}\right)$

$\mathrm{r}_{\mathrm{NO2}-\mathrm{N}}$ denitrification rate $\left(\mathrm{mg} \mathrm{NO}_{2}-\mathrm{N} / \mathrm{L} \cdot \mathrm{h}, \mathrm{mg}\right.$ $\mathrm{NO}_{2}-\mathrm{N} / \mathrm{g}$ VSS $\left.\cdot h\right)$

$\mathrm{t}$ time (hours)

In the SBR-D1 reactor, with acetic acid as the carbon source, the denitrification rate was $9.12 \mathrm{NO}_{2}-\mathrm{N} / \mathrm{g}$ VSS $h \mathrm{~h}$ and nitrite reduction lasted about five hours. A higher denitrification rate $-14.6 \mathrm{mg} \mathrm{NO}$ - N/g VSS $\cdot h$ obtained in SBR-D2 using butyric acid caused that total nitrite reduction to last just three hours of the cycle time (Figure 4).

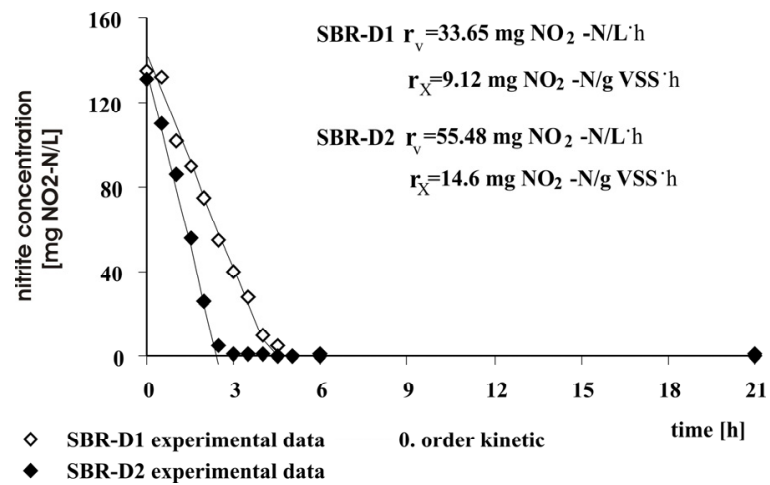

Figure 4: Concentration profiles of nitrite during anoxic conditions in SBR-D and reaction rates described by zero-order kinetics 
The denitrification rate is very significant because of its practical use. From the results obtained, it can be concluded that the use of acetic acid causes a reduction in the cycle time of the SBR-D from 24 hours to 12 hours, while using butyric acid causes a reduction from 24 hours to 8 hours.

Investigations related to the denitrification rate in leachate with an external carbon source have been conducted by many researchers, but most of these studies concerned denitrification via nitrate. Welander et al. (1998), during leachate treatment with methanol, obtained a denitrification rate equal to $55 \mathrm{~g} \mathrm{~N} / \mathrm{m}^{3} \cdot \mathrm{h}$. Foglar and Briski (2003) defined the methanol influence on the nitrate removal rate from synthetic wastewater. The total denitrification in that study was obtained for a $\mathrm{CH}_{3} \mathrm{OH} / \mathrm{NO}_{3}-\mathrm{N}$ ratio greater than 2.5 and was accompanied by a nitrate reduction rate of $4.35 \mathrm{mg} \mathrm{NO}$ - $\mathrm{N} / \mathrm{L} \mathrm{h}$. The study of Nyberg et al. (1996) resulted in a denitrification rate of $3 \mathrm{mg} \mathrm{N} / \mathrm{g}$ VSS·h with methanol as carbon source, but for ethanol it was three times higher. Furthermore, Louzeiro et al. (2002) showed that the denitrification rate increased with increasing methanol concentration, until a maximum denitrification rate of $19 \mathrm{mg} \quad \mathrm{NO}_{\mathrm{X}}-\mathrm{N} / \mathrm{g} \quad \mathrm{VSS} \cdot \mathrm{d}$ (0.8 mg $\mathrm{NO}_{\mathrm{X}}-\mathrm{N} / \mathrm{g}$ VSS $h$ ) was obtained for a methanol dose of $2.87 \mathrm{mg} \mathrm{CH} \mathrm{CH}_{3} \mathrm{OH} / \mathrm{mg} \mathrm{NO}_{\mathrm{X}}-\mathrm{N}$. To promote denitrification in leachate, Doyle et al. (2001) used maltose, acetate, and methanol as external carbon sources. They showed that, at a COD to $\mathrm{N}_{\text {removed }}$ ratio of between 7.2 and 7.4, the denitrification rate varied from $6.67 \mathrm{mg} / \mathrm{g}$ VSS $\mathrm{h}$ (methanol, acetate) to $7.08 \mathrm{mg} / \mathrm{g}$ VSS$\cdot h$ (maltose). Peng et al. (2007) showed that, in a pre-denitrification system with an external carbon source, the denitrification rates with ethanol, acetate, and methanol reached values as high as 9.6, 12 , and $3.2 \mathrm{mg} \mathrm{N} / \mathrm{g} \mathrm{VSS} \cdot \mathrm{h}$, respectively.

The denitrification rate via the nitrite route obtained in our study was high compared with the rate of denitrification via nitrate. Similarly, Chung and Bae (2002) showed that, in SBR with glucose as the sole electron donor and sodium nitrite as the sole electron acceptor, the average specific nitrite reduction rate was $50.1 \mathrm{mg} / \mathrm{g}$ VSS $\mathrm{h}$ and the nitrate reduction rate only $13.75 \mathrm{mg} / \mathrm{g}$ VSS $\cdot h$. However, the maximum denitrification rate for nitrite was as much as 4.3 times faster than the rate of nitrate reduction. In contrast, Akunna et al. (1993), in batch-tests with different carbon sources showed that in the case of acetic and lactic acids, the nitrite reduction rate was about $14 \%$ lower than the nitrate reduction rate.

From a biochemical point of view, nitrite appears to be the preferred electron acceptor since the nitrite reductase is located closer to the environment (periplasmic space) than the nitrate reductase (cytoplasmic side of the membrane) (Hochstein and Tomlinson, 1988; Stouthamer, 1988; Brittain et al., 1992; Schulthess et al., 1995; Moreno-Vivian et al., 1999; Chung and Bae, 2002), which means that nitrite has less transport resistance. In this study, both carbon sources gave fast reaction rates since the microorganisms had been grown on them and were well adapted to that carbon source. Moreover no inhibition was observed at the concentrations of nitrite to which the microorganisms were adapted. Chung and Bae (2002) also confirmed that the nitrite denitrification was self-inhibited only in the case when nitrite was present above the concentration to which the microorganisms had been acclimated.

\section{CONCLUSIONS}

The integration of short-cut nitrification and denitrification via nitrite with an external carbon source process may be applied in a two-stage SBR system for nitrogen removal from mature landfill leachate. It was shown that short-cut nitrification can be achieved by reducing the oxygen concentration in the nitrifying reactor. Low oxygen levels during treatment may bring about great savings in aeration. The complete removal of nitrite was obtained at a carbon dose of $2.4 \mathrm{mg} \mathrm{COD} / \mathrm{mg} \mathrm{NO} \mathrm{NO}_{2}-\mathrm{N}$ for acetic acid and $3.8 \mathrm{mg} \mathrm{COD} / \mathrm{mg} \mathrm{NO} \mathrm{N}_{2}-\mathrm{N}$ for butyric acid. A high denitrification rate $-9.12 \quad \mathrm{NO}_{2}-\mathrm{N} / \mathrm{g}$ VSS $\cdot h$ (acetic acid) and $14.6 \mathrm{NO}_{2}-\mathrm{N} / \mathrm{g} \mathrm{VSS} \cdot \mathrm{h}$ (butyric acid) - allows for a significant reduction in the SBR-D reaction cycle.

\section{NOMENCLATURE}

\begin{tabular}{|c|c|c|}
\hline $\mathrm{C}_{\mathrm{NH} 4-\mathrm{N}}$ & $\begin{array}{l}\text { ammonium } \\
\text { concentration after } \\
\text { time } t\end{array}$ & $\mathrm{mg} \mathrm{NH}_{4}-\mathrm{N} / \mathrm{L}$ \\
\hline $\mathrm{C}_{(\mathrm{NH} 4-\mathrm{N}) 0}$ & $\begin{array}{l}\text { ammonium } \\
\text { concentration at the } \\
\text { beginning of the } \\
\text { aeration phase }\end{array}$ & $\mathrm{mg} \mathrm{NH}_{4}-\mathrm{N} / \mathrm{L}$ \\
\hline $\mathrm{C}_{\mathrm{NO} 2-\mathrm{N}}$ & $\begin{array}{l}\text { nitrite concentration } \\
\text { after time } t\end{array}$ & $\mathrm{mg} \mathrm{NO} \mathrm{N}_{2}-\mathrm{N} / \mathrm{L}$ \\
\hline $\mathrm{C}_{(\mathrm{NO2}-\mathrm{N}) 0}$ & $\begin{array}{l}\text { nitrite concentration at } \\
\text { the beginning of the } \\
\text { SBR operating cycle }\end{array}$ & $\mathrm{mg} \mathrm{NO}{ }_{2}-\mathrm{N} / \mathrm{L}$ \\
\hline DO & $\begin{array}{l}\text { dissolved oxygen } \\
\text { concentration }\end{array}$ & $\mathrm{mgO}_{2} / \mathrm{L}$ \\
\hline $\mathrm{k}_{\mathrm{NH4-N}}$ & $\begin{array}{l}\text { constant of the } \\
\text { ammonium nitrogen } \\
\text { removal rate }\end{array}$ & $\begin{array}{r}\mathrm{mg} \mathrm{NH}_{4}-\mathrm{N} / \mathrm{L} \cdot \mathrm{h}, \\
\mathrm{mg} \mathrm{NH} \mathrm{NH}_{4} \mathrm{~N} / \mathrm{g} \text { VSS} \cdot \mathrm{h}\end{array}$ \\
\hline
\end{tabular}


218

$\mathrm{k}_{\mathrm{NO} 2-\mathrm{N}}$

constant of the denitrification rate

VFA

volatile fatty acids

$\mathrm{n} \quad$ volumetric exchange

rate

$\mathrm{r}_{\mathrm{NH} 4-\mathrm{N}}$

ammonium nitrogen

removal rate

$\mathrm{r}_{\mathrm{NO} 2-\mathrm{N}}$

denitrification rate

$\mathrm{t}$

time $\mathrm{mg} \mathrm{NO}-\mathrm{N} / \mathrm{L} \cdot \mathrm{h}$, mg $\mathrm{NO}_{2}-\mathrm{N} / \mathrm{g} \mathrm{VSS} \cdot \mathrm{h}$

$\mathrm{d}^{-1}$

$\operatorname{mg~} \mathrm{NH}_{4}-\mathrm{N} / \mathrm{L} \cdot \mathrm{h}$, mg $\mathrm{NH}_{4}-\mathrm{N} / \mathrm{g} \mathrm{VSS} \cdot \mathrm{h}$ $\mathrm{mg} \mathrm{NO}-\mathrm{N} / \mathrm{L} \cdot \mathrm{h}$, mg $\mathrm{NO}_{2}-\mathrm{N} / \mathrm{g} \mathrm{VSS} \cdot \mathrm{h}$ hours

\section{REFERENCES}

Akunna, J. C., Bizeau, C. and Moletta, R., Nitrate and nitrite reductions with anaerobic sludge using various carbon sources: glucose, glycerol, acetic acid, lactic acid and methanol. Water Research, 27, p. 1303 (1993).

Avezzu, F., Bissolotti, G. and Collivignarelli, C., Combination of wet oxidation and activated sludge treatment, in: Christensen, T. H., Cossu, R. and Stegmann, R., (Eds.), Landfilling of waste: leachate. Elsevier applied science. London and New York, p. 333 (1992).

Aziz, A. H., Alias, S., Adlan, M. N., Asaari, F. A. H. and Zahari, M. S., Colour removal from landfill leachate by coagulation and flocculation processes. Bioresource Technology, 98, p. 218 (2007).

Carley, B. N. and Mavinic, D. S., The effects of external carbon loading on nitrification and denitrification of a high-ammonia landfill leachate. Research Journal Water Pollution Control Federation, 63, p. 51 (1991).

Carrera, J., Baeza, J. A. and Lafuente, T., Biological nitrogen removal of high-strength ammonium industrial wastewater with two-sludge system. Water Research, 37, p. 4211 (2003).

Chan, G. Y. S., Chu, L. M. and Wong, M. H., Effects of leachate recirculation on biogas production from landfill co-disposal of municipal solid waste, sewage sludge and marine sediment. Environmental Pollution, 118, p. 393 (2002).

Christensson, M., Lie, E. and Welander, T., A comparison between ethanol and methanol as carbon source for denitrification. Water Science and Technology, 6/30, p. 83 (1994).

Chugh, S., Clarke, W., Pullammanappallil, P. and Rudolph, V., Effect of recirculated leachate volume on MSW degradation. Waste Management and Research, 16, p. 564 (1998).

Chung, J. and Bae, W., Nitrite reduction by a mixed culture under conditions relevant to shortcut

biological nitrogen removal. Biodegradation, 13, p. 163 (2002).

Doyle, J., Watts, S., Solley, D., Keller, J., Exceptionally high - rate nitrification in sequencing batch reactors treating high ammonia landfill leachate. Water Science and Technology, 3/43, p. 315 (2001).

Eilersen, A. M., Henze, M. and Kløft, L., Effect of volatile fatty acids and trimethylamine on denitrification in activated sludge. Water Research, 5/29, p. 1259 (1995).

Foglar, L. and Briški, F., Wastewater denitrification process - the influence of methanol and kinetic analysis. Process Biochemistry, 39, p. 95 (2003).

Fux, Ch., Velten, S., Carozzi, V., Solley, D. and Keller J., Efficient and stable nitritation and denitritation of ammonium-rich sludge dewatering liquor using an SBR with continuous loading. Water Research, 40, p. 2765 (2006).

Hallin, S. and Pell, M., Metabolic properties of denitrifying bacteria adapting to methanol and ethanol in activated sludge. Water Research, 1/32, 13-18 (1998).

Hermanowicz, W., Dożańska, W., Dojlido, J. and Koziorowski, B., Fizyczno - chemiczne badanie wody i ścieków. Arkady, Warszawa (1999). (In Polish).

Hellinga, C., Schellen, A. A. J. C., Mulder, J. W., van Loosdrecht, M. C. M. and Heijnen, J. J., The SHARON process: an innovative method for nitrogen removal from ammonium - rich wastewater. Water Science and Technology, 9/37, p. 135 (1998).

Ilies, P. and Mavinic, D. S., The effect of decreased ambient temperature on the biological nitrification and denitrification of a high ammonia landfill leachate. Water Research, 35, 2065-2072 (2001a).

Ilies, P. and Mavinic, D. S., Biological nitrification and denitrification of a simulated high ammonia landfill leachate using 4-stage Bardenpho systems: system startup and acclimation. Canadian Journal of Civil Engineering, 28, p. 85 (2001b).

Jianlong, W. and Jing, K., The characteristic of anaerobic ammonium oxidation (ANAMMOX) by granular sludge from an EGSB reactor. Process Biochemistry, 40, p. 1973 (2005).

Kaczorek, K. and Ledakowicz, S., Kinetics of nitrogen removal from sanitary landfill leachate. Bioprocess Biosystem Engineering, 29, p. 291 (2006).

Kang, K-H., Shin, H. S. and Park, H., Characterization of humic substances present in landfill leachates with different landfill ages and its implications. Water Research 36, p. 4023 (2002). 
Klimiuk, E. and Kulikowska, D., Effectiveness of organics and nitrogen removal from municipal landfill leachate in single and two-stage SBR system. Polish Journal of Environmental Studies 5/13, p. 517 (2004).

Kulikowska, D. and Klimiuk, E., Removal of organics and nitrogen from municipal landfill leachate in two-stage SBR reactors. Polish Journal of Environmental Studies, 4/13, p. 389 (2004).

Kurniawan, T. A., Lo, W-H. and Chan, G. Y. S., Degradation of recalcitrant compounds from stabilized landfill leachate using a combination of ozone-GAC adsorption treatment. Journal of Hazardous Materials, B137, p. 433 (2006).

Louzeiro, N. R. D., Mavinic, S., Oldham, W. K., Meisend, A. and Gardnere, I. S., Methanolinduced biological nutrient removal kinetics in a full-scale sequencing batch reactor. Water Research, 36, p. 2721 (2002).

Mulder, J. W. and van Kempen, R., N-removal by SHARON. Water Quality International, 2, p. 30 (1997).

Mulder, J. W., van Loosdrecht, M. C. M., Hellinga, C. and van Kempen, R., Full-scale application of the SHARON process for treatment of rejection water of digested sludge dewatering. Water Science and Technology, 11/43, p. 127 (2001).

Nyberg, U., Andersson, B. and Aspegren, B. H., Long-term experiences with external carbon sources for nitrogen removal. Water Science and Technology, 33, p. 109 (1996).

Peng, Y., Ma, Y. and Wang, S., Denitrification potential enhancement by addition of external carbon sources in a pre-denitrification process. Journal Environmental Science, 3/9, p. 284 (2007).

Queiroz, L. M., Aun, V., Morita, D. M. and Sobrinho, P. A., Biological nitrogen removal over nitritation/denitritation using phenol as a carbon source. Brazilian Journal of Chemical Engineeering, 28, p. 197 (2011).

Reinhart, D. R. and Yousfi, A. B., The impact of leachate recirculation on municipal solid waste operating characteristics. Waste Management and Research, 14, p. 337 (1996).

Ruiz, G., Jeison, D. and Chamy, R., Nitrification with high nitrite accumulation for the treatment of wastewater with high ammonia concentration. Water Research, 32, p. 1371 (2003).

Schmidt, I., Sliekers, O., Schmidt, M., Cirpus, I., Strous, M., Bock, E., Kuenen, J. G. and Jetten, M. S. M., Aerobic and anaerobic ammonia oxidizing bacteria - competitors or natural partners? FEMS Microbiology Ecology, 39, p. 175 (2002).

Schmidt, I., Sliekers, O., Schmid, M., Bock, E., Fuerst, J., Kuenen, J. G., Jetten, M. S. M. and Strous, M., New concepts of microbial treatment processes fort he nitrogen removal in wastewater. FEMS Microbiology Review, 27, p. 481 (2003).

Standard Methods for the examination of water and wastewater, Edited by Greenberg, A. E., Clesceri, L. S., Eaton, A. D., (1992).

Timur, H. and Özturk, I., Anaerobic sequencing batch reactor treatment of landfill leachate. Water Research 33, p. 3225 (1999).

Trebouet, D., Schlumpf, J. P., Jaouen, P. and Quemeneur, F., Stabilized landfill leachate treatment by combined physicochemicalnanofiltration processes. Water Research, 35, p. 2935 (2001).

Villaverde, S., Garciá-Encina, P. A. and FdzPolanco, F., Influence of $\mathrm{pH}$ over nitrifying biofilm activity in submerged biofilmers. Water Research, 31, p. 1180 (1997).

Wang, X., Ma, Y., Peng, Y. and Wang, S., Short-cut nitrification of domestic wastewater in a pilotscale $\mathrm{A} / \mathrm{O}$ nitrogen removal plant. Bioprocess Biosystem Engineering, 30, p. 91 (2007).

Welander, U., Henrysson, T. and Welander, T., Biological nitrogen removal from municipal landfill leachate in a pilot scale suspended carrier biofilm process. Water Research, 32, p. 1564 (1998). 